\title{
Clowns, buffoons and the killing laugh: An investigation of the Clandestine Insurgent Rebel Clown Army's (CIRCA) power to disrupt and provoke through joy and humour
}

\author{
Hilary Ramsden \\ University of South Wales, Cardiff, UK \\ hilary.ramsden@southwales.ac.uk
}

\begin{abstract}
This essay offers an experiential account of the development of "rebel clowning" as a practice that emerged in the context of the anti-globalisation movements in the UK, bringing together the ancient art of clowning and more recent practices of non-violent direct action. The essay traces the legacies of rebel clowning, outlines the tactics and strategies that comprise its humour, and analyses key activist moments in its trajectory in the first decade of the $21^{\text {st }}$ century. By inserting the logic of clowning into the activist realm, the essay argues, the tired binary between protester and authority, or activists and their opponents, is shaken and cheerfully disrupted.
\end{abstract}

Keywords: rebel clown, buffoon, disruption, alterglobalisation.

On Police radio, during an action against NSA Menwith Hill spy base, the voice of a police commander was heard, nervously trying to alert reinforcements: ' ....the clowns are organising... the clowns are organising - over and out...'

(Klepto and Up Evil 2005: 243.)

\section{Introduction: release through clowning}

A highly unusual communication that signalled highly unusual troop manoeuvres: the police commander on the radio in the quote above was referring to gaggles of rebel clowns, dressed in flamboyant combinations of army camouflage uniforms, pink and green fake fur, colanders, stripey socks, armed with noisemakers, string, sausages, sex toys, glitter, bubbles, bouncy balls and whistles, who were converging with protesters who had come to declare Independence From 
America. Rebel clowning was in its beginnings, and police and security forces were still unsure how to respond to these slippery, giggling, apparently dim-witted creatures that appeared to have just arrived from a child's party.

Rebel clowning is a form of political activism that brings together the ancient art of clowning and more recent practices of non-violent direct action. This photo essay examines how the Clandestine Insurgent Rebel Clown Army (CIRCA hereafter) in its short and explosive trajectory, contributed to the transformation and radicalization of public space on a number of levels, subverting binary power structures through non-violent direct action. This was only possible through the means and power of humour and laughter and through the development of a "rebel clown" - a hybrid drawing on the traditions of clown and buffoon.

As a co-founder of CIRCA, and rebel clown trainer with the formal title of "General Confusion", I experienced how practices of rebel clowning can create opportunities, akin to a Situationist détournement, where a new kind of vision and imagination, emerging through a particular kind of stupidity and clown logic, can lead to different modes of thinking and acting. The essay explores how this form of embodiment presents opportunities for new relationships, complicities, and encounters that emerge from this state of rebel clown.

Although the theme of this issue and therefore article does not allow for a deeper investigation of the history of clowning, it is useful to point out key elements that informed CIRCA's development of rebel clown. Davison argues that because "clown starts from the acceptance that we inevitably fail, stories and experiences which seem impossible to express, and which we feel doomed to never succeed in overcoming, can be addressed" (2013: 299). Salverson further suggests: "It is impossible to face the story of the atomic bomb and its consequences with comprehension. Clowning offered a way to name this possibility" (2008: 35). Humour, comedy, and clowning offer opportunities for the intangible and ephemeral precariousness of life and humanity to be unpicked and examined without fear, for taboos to be broached and lines overstepped. The rebel clown known by the name Kolonel Klepto observes: "Laughter releases. It opens the body and mind, throwing it into a transformative chaos" (2004: 410). This release began a transformation that allowed activists to step out of a familiar binary of protester vs. authority.

\section{New clown traditions}

My own clown training started in 1977 at an evening class with clown and musician, Rosina Sonnenschmidt in Stuttgart, and continued throughout the 1980s and 1990s, working with a number of European teachers including Peta Lily, John Lee, Monika Pagneux, and Philippe Gaulier, who were all working with new approaches to the clown, which was neither the children's party clown of Ronald McDonald, nor the scary clown portrayed by Jack Nicholson in Hollywood films. It moved away from the traditions of the circus clown and rehearsal of clown numbers towards a more theatrical clown whose work was based on "play" and on finding "your own clown". These notions became fundamental to providing activists with a way to personalise their performance of activism through clowning rather than to follow practices of clowning through rehearsing traditional circus clown gags.

In 2004, along with clown Danny Schlesinger, I was invited to a retreat in Wiltshire, UK, organised through the Live Art Development Agency, by activist and artist John Jordan and asked to train activists in clown and buffoon. We spent an intensive three days facilitating games and exercises with 30 participants, cooking and eating together, discussing non-violent direct 
actions tactics and philosophies in order to create new methods to subvert and differently respond to repressive police tactics in confrontational situations. We also developed games, exercises, and ideas for interventions that would surprise and delight spectators/audiences and other participants on demonstrations and protests (Fremeaux and Ramsden 2007). We created rebel clown drills, a salute, and took on self-ridiculing, parodic names such as Major Fuck-Up (Danny) and General Confusion (myself). Many of these names were wordplays in themselves, such as Major Up Evil (from "major upheaval") and Private Parts (from "private parts", i.e. genitalia). We made costumes - army uniforms trimmed with pink and green fake fur, helmets created out of colanders. The beginning of CIRCA was formalised and developed here and it was the start of many interventions and actions on the part of activists who were tired of feeling burned out on anger, negativity, and lost causes. Simplistically (and successfully), CIRCA worked on the notion of subverting the binary relationships between protester and police, activist and authority, obedience and disobedience, permission and prohibition to redress power imbalances through humour and laughter (Figure 1).

\section{The hybrid rebel clown}

My approach to teaching buffoon to activists was based on Philippe Gaulier's (2012) story of the medieval buffoon, who was an outcast from society - outcasts being those who were disabled, drunks, mentally unstable, or sexually deviant - and who lived on the margins in a community of buffoons. Once a year these buffoons would be invited back into the medieval town from which they had been banished to provide entertainment for high society. The entertainment consisted of parodies of the powerful people in this society, often the very ones who had cast them out. The intention of the buffoons was to cause those in power to laugh so much at their clever parodies that they would have a crise cardiaque (heart attack) and die. The enemy would literally be attacked by the weapon of laughter. Is it coincidental that man's laughter can be manslaughter? Working with activists over those three days, I realized that this story provided a perfect context for this new practice, giving me a fresh perspective to connect my own activism with my work as a clown. This exploration of authoritarianism through parody and ridicule stimulated creativity and imagination, addressing issues of coercion, self-censorship, and inhibitions and releasing the subversive power of play (Klepto 2004).

The rebel clown, then, became a hybrid of the naïve, red-nose clown who uses play, the individual clown persona, and the more cunning, spiteful buffoon who seeks revenge through the killing laugh and who then retreats with her group, apologising when she realizes she has overstepped a boundary: "The art of the fool is to feel when you're on someone's boundary, hold it for a moment, then come back off as if to say 'oh but I'm just a poor fool, what do I know?" (Anderson quoted in Davison 2013: 299). It is this self-deprecating retraction, the apology after the taunt or transgression that marks a significant difference in tactics for activists previously accustomed to persevering with a more confrontational approach.

Inheriting from the legacies of feminism and queer activism in the 1980s in the UK, as well as from groups such as Reclaim the Streets throughout the 1990s, rebel clowning became a popular activist strategy precisely because it eclectically combined elements often seen as distinct from the political realm: celebration, pleasure, desire, diversity, a seeming lack of intelligence, chaos, and horizontal power structures. Seeing both the soul and the street as sites of struggle and transformation, rebel clowning is a practice that attempts to transform and sustain 
the emotional life of those engaged in social change, as well as being an effective tool for direct action.

\section{Tactics and strategies: parody and play}

One of CIRCA's first actions involved a gaggle of clowns in Leeds in 2004 attempting to enlist as soldiers in a local army and navy recruiting office. The delightful mayhem and chaos that ensued resulted in the office being shut (Figure 2). It was a genius plan: a space normally reserved for the enlisting of young men and women to services which deal in war and violence was overturned and made powerless through laughter, stupidity, and misunderstanding. The relational space between police and activists, previously characterized by anger and negativity, is subverted through giggling and deliberate misunderstanding. Both can be regarded as key elements of clowning: the ability to laugh at oneself and the failure of one's own actions (Davison 2013), which might be seen as the failure to enlist in any of the military services; and deliberate misunderstanding, wondering why we can't have the big guns displayed on the recruitment posters, or why are we being asked to leave the building when we only want to join in?

The clowns then played with and performed to passers-by in front of the office, transforming and radicalizing public spaces, inviting them to enlist in their own rebel clown army. The rebel clown offers no rational argument for or against an issue, identifying it as stupid - s/he merely follows a clown logic that consists of joyful disruption and laughter. This action set the tone for many interventions that followed: parody our oppressors, become the security forces rather than oppose them, play with and assist them in protecting and preserving the status quo. Following clown logic, bafflement, and misunderstanding we turned the repressive behaviour, as well as violent direct action, on its head. Rebel clowning turns fear of authority and arrest into a game of "Tag" or "Grandmothers' Footsteps". Instead of resisting, the clown collaborates; instead of obeying, the clown misunderstands: John Wright maintains that the clown tends to start from a place of bafflement (2006: 194), she asks a question, offers an alternative order. By parodying authority the rebel clown at once temporarily identifies with it and assumes its identity (Figures 3 $\& 4)$. The clown allows fun to be made of her and her actions: she slips on a banana peel and falls, the audience (in this case, the army, police, or security force) can laugh at her, experiencing relief that they themselves are not humiliated. Yet they end up in a contradictory position: they "fail" by their own standards because their usual violent tactics are rendered ineffective in controlling the clown (Figure 5).

\section{Tactics and strategies: failure and foolishness}

Foolishness and failure are key elements in clown training, and learning to accept these requires practice. Clara Cenoz argues that the ego is the obstacle to accepting failure, for the ego is based "on the defence of our personality... on a system of fears and desires" (quoted in Davison 2013: 309). Once we understand that we are not our ego, we need no longer fear that we do not fulfill the demands of these fears and desires. We no longer need to fear failure. This is why, Cenoz maintains, "people feel this liberation with clown" (quoted in Davison 2013: 309). Klepto suggests that "[A]ctivist culture is often paralysed by the desire to get things right. The fear of not creating the perfect action or campaign that will change the world, can be an enormous block 
to creativity" (2004: 408). The notion of embracing failure therefore forms a crucial part of rebel clown practice and can be understood as characterising its unique approach to humour (Figure 6).

Consequently, activists no longer had to appear angry and negative; we were no longer having to say "no" in a direct binary confrontation with our opponents. We had permission and freedom to fail, to be stupid, to celebrate, to play:

During a [public] action against a conference for the corporate "reconstruction" of Iraq, a highranking [police] officer leaned over to one of the clowns and said, "Can I have a serious word?" "A serious word" echoed [rebel clown] Coco Bella, with his nasal twang, "what is a serious word? Is 'encyclopedia' a serious word?"' The officer retreated, unable to communicate with the universe of the clown.

(Klepto 2004: 410.)

During an action at Menwith Hill spy base, police formed a line to block protesters. Clowns "assisted" them by forming their own line - in front of the police, effectively blocking them from the protesters. A police order to "Stand behind the line!" (meaning behind the road markings) was repeated many times by many clowns, inspiring improvisations around notions of what the word "line" meant, until the phrase became meaningless and ineffective (Klepto 2004) (Figure 7). When confrontation is expected, with the police or the security guard of a corporate building, for instance, the clown offers assistance in securing the building, thereby completely deflating the importance of both the building and the security forces. For many activists, being in a state of rebel clown was completely electrifying and it changed their ways of working, albeit for a brief time.

\section{Carnival}

In its merging of the political and the aesthetic, carnival was inspirational for CIRCA as a form of resistance, just as it has become a key tactic in global anti-capitalist movements in the last two decades of the $20^{\text {th }}$ century (Notes from Nowhere 2002). Carnival is about joyful disruption, unpredictability, spontaneity, and inventiveness (Figure 8). The inspiration for such understanding of carnival is to be found notably in the theories of Mikhail Bakhtin, who suggests carnival offers "moments of death and revival, of change and renewal [...]. It belongs to the borderline between art and life. In reality, it is life itself, but shaped accordingly to a certain pattern of play" (1984: 7). For both Bakhtin and the 1960s radical avantgarde known as the Situationists, carnival was a "unitary 'world' of social relations that were independent and distinct from those of everyday life. These relations were characterised by the inversion of hierarchical relationships where the low mocked the high, and all dogmas and hierarchies were suspended" (Grindon 2004: 149). Bakhtin suggests that carnival offers "the chance [...] to enter a completely new order of things" (1984: 34) which was a great attraction for rebel clown activists. Carnival offered activists an immediate transformation of reality rather than the deferred gratification of tomorrow's revolution. The clown training adopted Bakhtin's call to make no distinction between actors and spectators (1984: 168), thus making it possible for anyone to enlist as a rebel clown. 


\section{The Ridiculous Recruitment Show}

Carnival and conviviality were core elements in the conceiving of The Ridiculous Recruitment Show, a radical moveable feast developed by a core group of rebel clowns, whose destination would be the G8 Summit in July 2005, in Gleneagles, Scotland. Funded largely by the Arts Council of England, it toured the UK and featured an information caravan, which also doubled as meeting space and changing room for performers, a theatre performance (Figure 9), videos of international activist work, radical origami, and free organic chips with revolutionary sauces served at the end of the evening before a mass participatory game of "Keepy-Uppy" with an inflatable world (Fremeaux and Ramsden 2007). Travelling in a bus fuelled by the oil that we had cooked the chips in, the gaggle of clowns invited audiences in each town to participate in games, performances, and eating. We offered two-day rebel clown trainings, calling on people to enrol in CIRCA (Figure 10) and to join in the direct non-violent rebel clown action at the protests during the G8 Summit.

CIRCA co-founder Kolonel Klepto recounts his observations of the carnivalesque atmosphere created at the politically highly charged event of the G8 (Figure 11):

Clowns hug policemen, policemen hug clowns. Everyone is a bit surprised, there is a roar of celebratory cheers from the clowns... and embarrassed applause from the police ... Somehow, this group of clowns managed to persuade the police to play a game with them. Known as Goblins, Wizards and Giants, it is a version of paper-scissor-stone, but played in teams with the whole body. One of the rules is that if both teams choose the same character, no one wins and they all have to hug. This is exactly what happened as clowns and police simultaneously chose to be Wizards.

(Klepto and Up Evil 2005: 244.)

Normal hierarchies and relationships are thus turned on their head. As riot police lined up in Edinburgh to prevent the G8 from being disrupted, brandishing their shields as a clear sign of authority and power, a tiara-wearing clown kisses and draws smiley faces with her lipstick to accompany the traces of her lips on the transparent plastic built to intimidate and repress (Klepto 2004) (Figure 12). Rebel clowns became the King's fools, creatures able to go where others dare not, able to touch forbidden places, transgress where others toe the line.

After converging in their hundreds at the G8 summit, rebel clowns became a worldwide phenomenon, spreading virally and rhizomatically, popping up anywhere and everywhere there were issues and injustices to be fought. Local clown gaggles were created in Germany, Israel, USA, Netherlands, France, Belgium, and Spain (Figures 13, 14, and 15). Rebel clowns became to the bastions of authority what the women of Greenham Common were to the American soldiers on the Greenham Common base: strange creatures that fell outside the established patterns of resistance (Feminism and Nonviolence Study Group 1983). Rebel clowning was a stunningly creative and effective way to wrong-foot authority through the power of laughter, self-ridicule, and collective foolishness. 


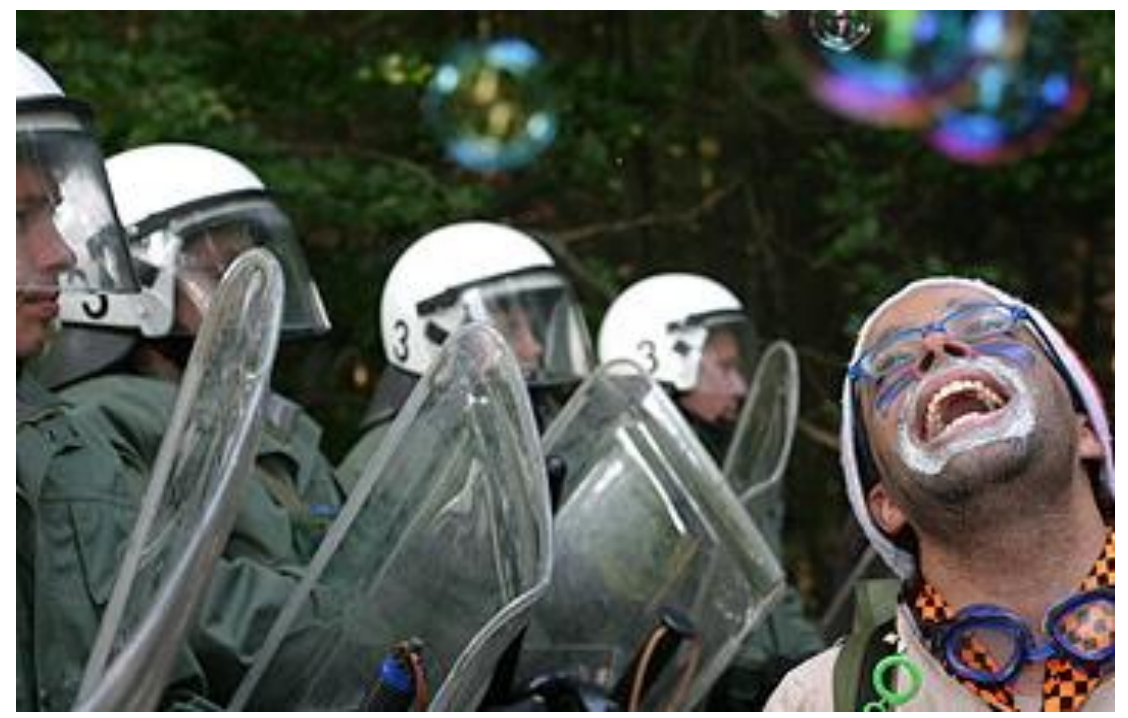

Figure 1. The subversive power and release of laughter.

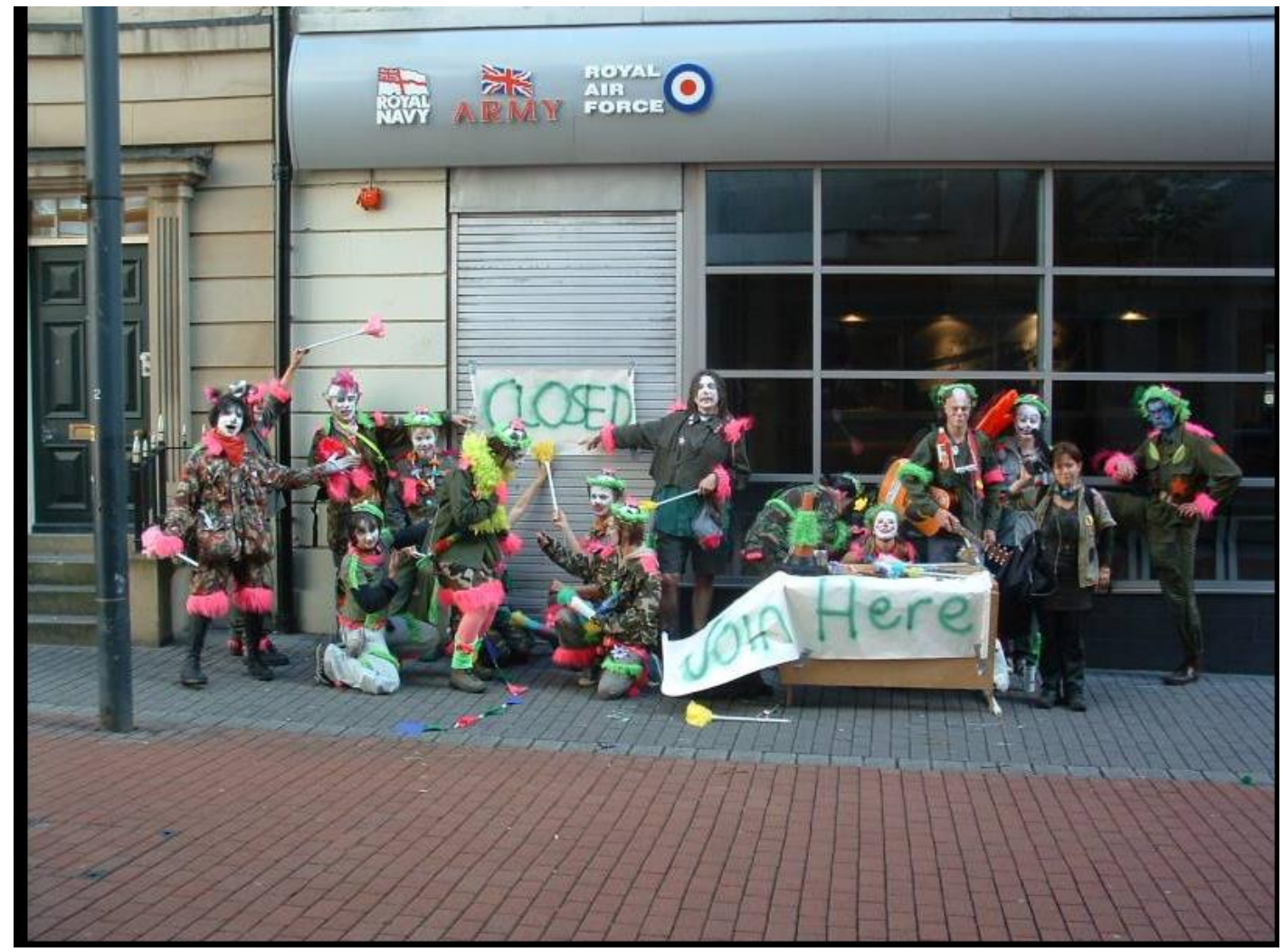

Figure 2. Military Recruiting Office in Leeds in closed: join the Rebel Clown Army here! 


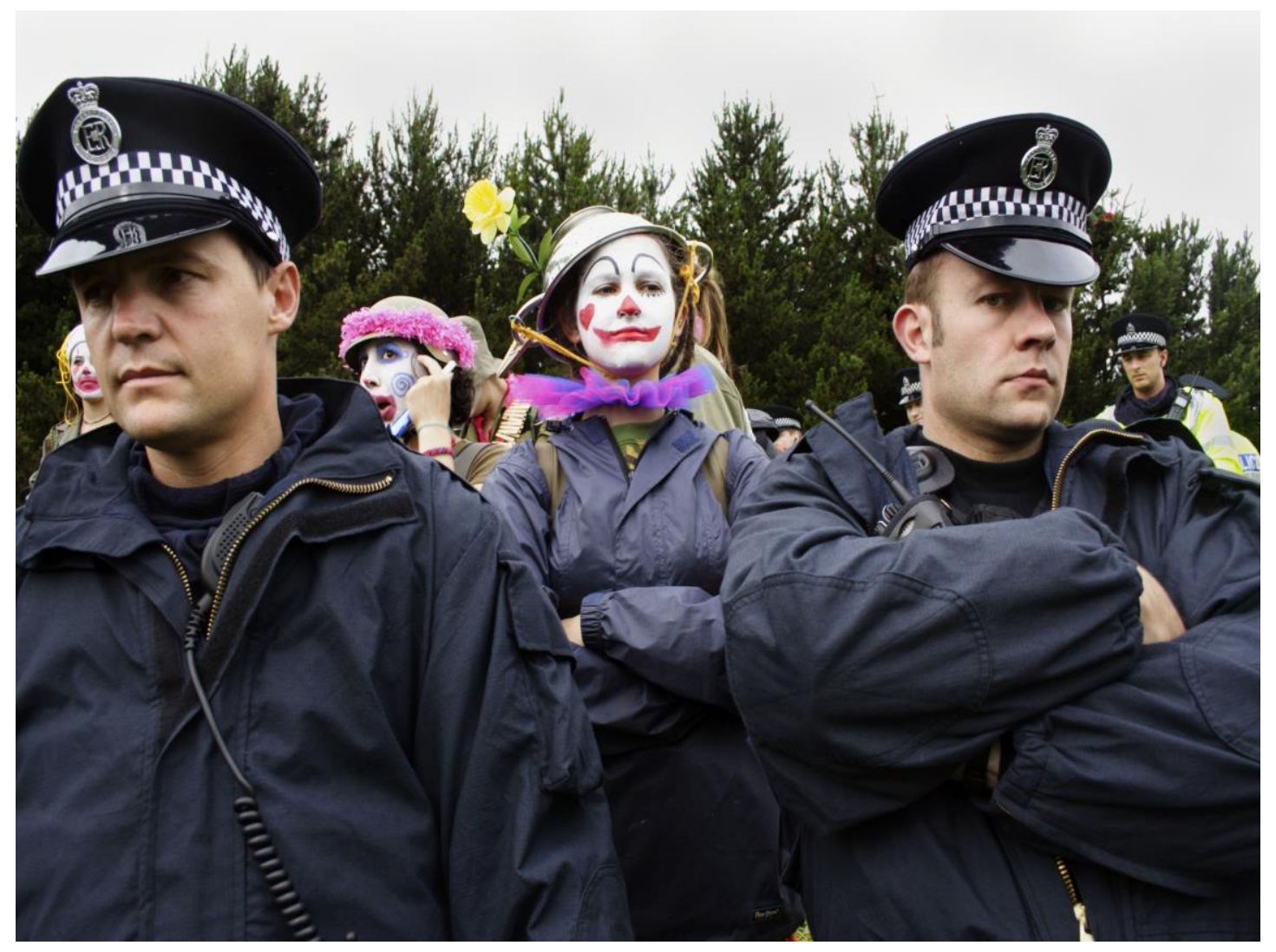

Figure 3. Parodying authority: Rebel Clowns join forces with the police. 


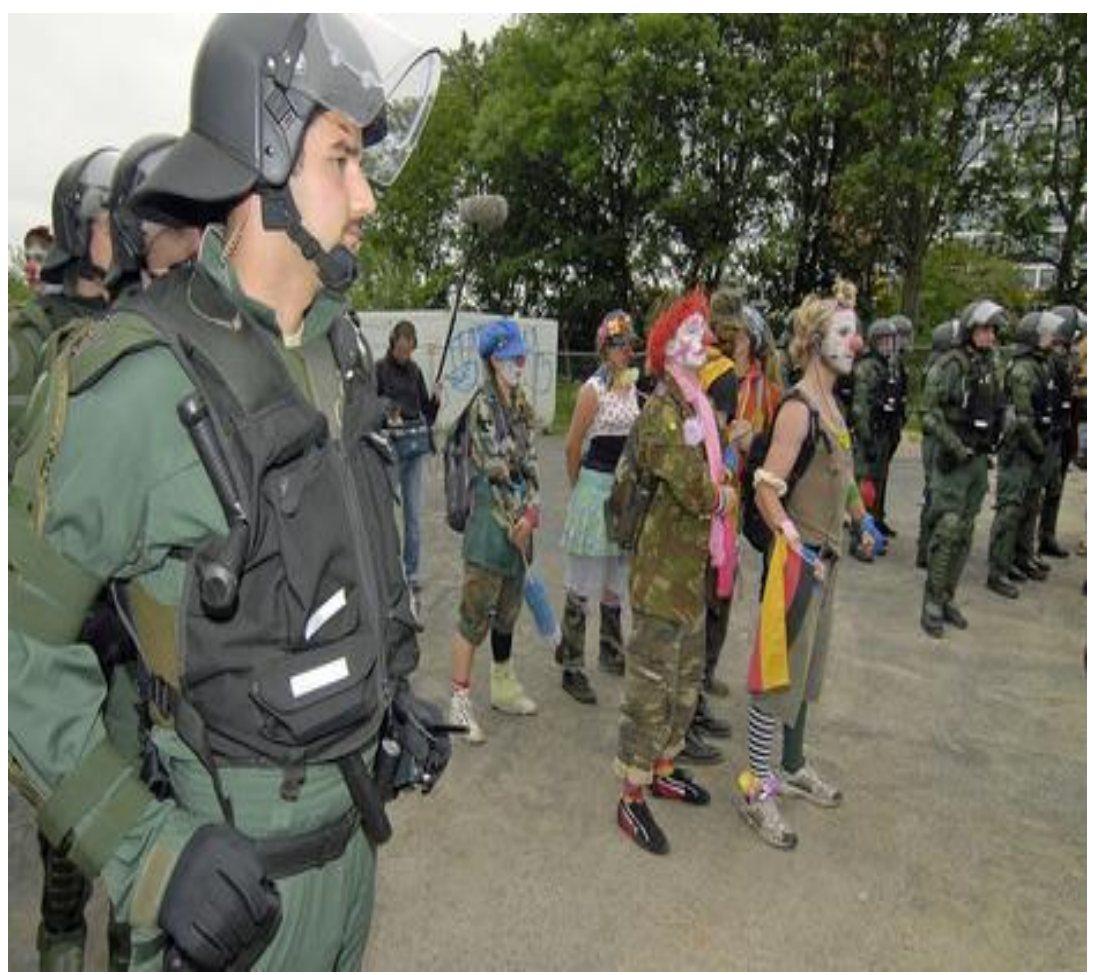

Figure 4. Parodying authority: the clown identifies with her oppressor. 


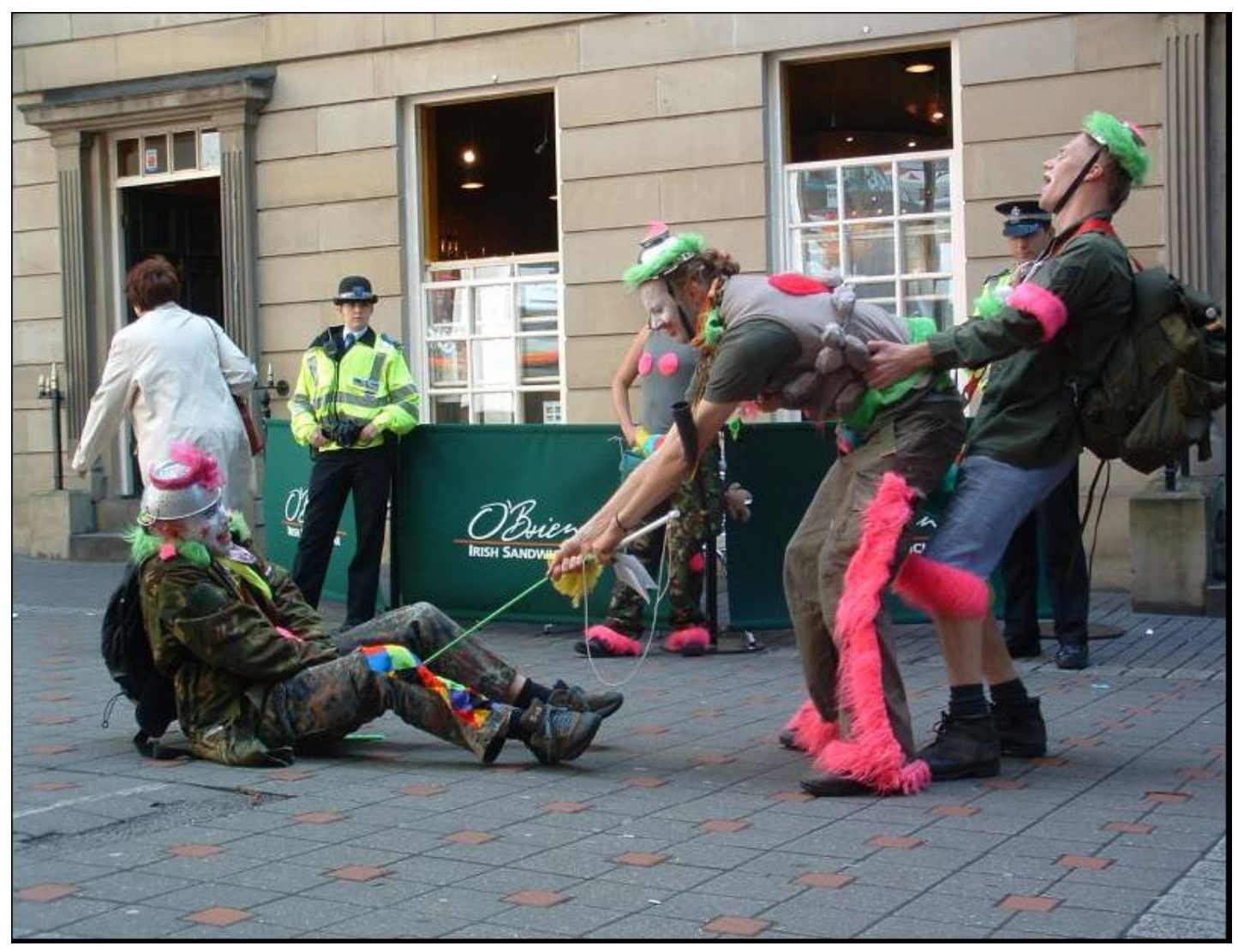

Figure 5. Following stupid clown logic, laughing at ourselves. 


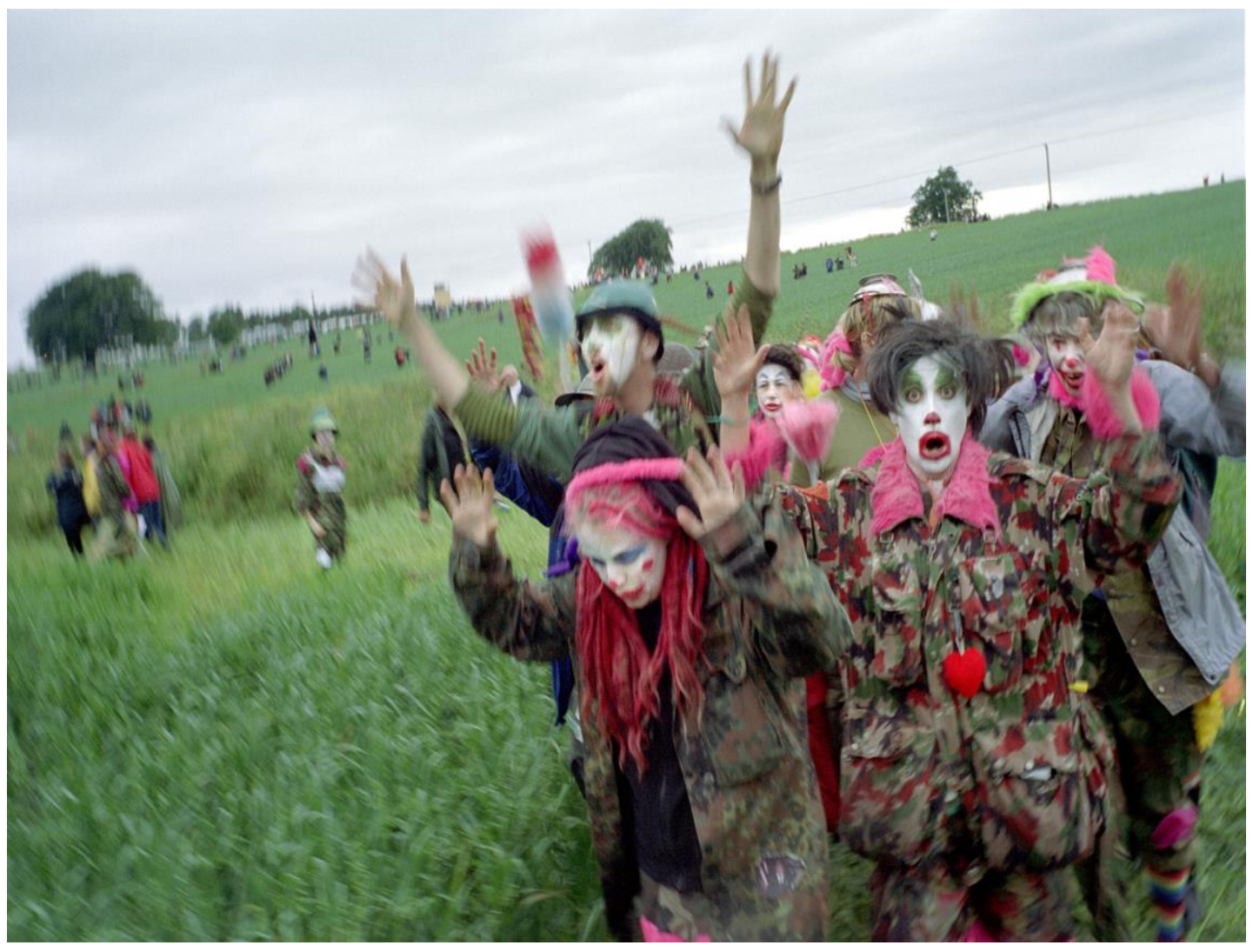

Figure 6. Embracing failure! 


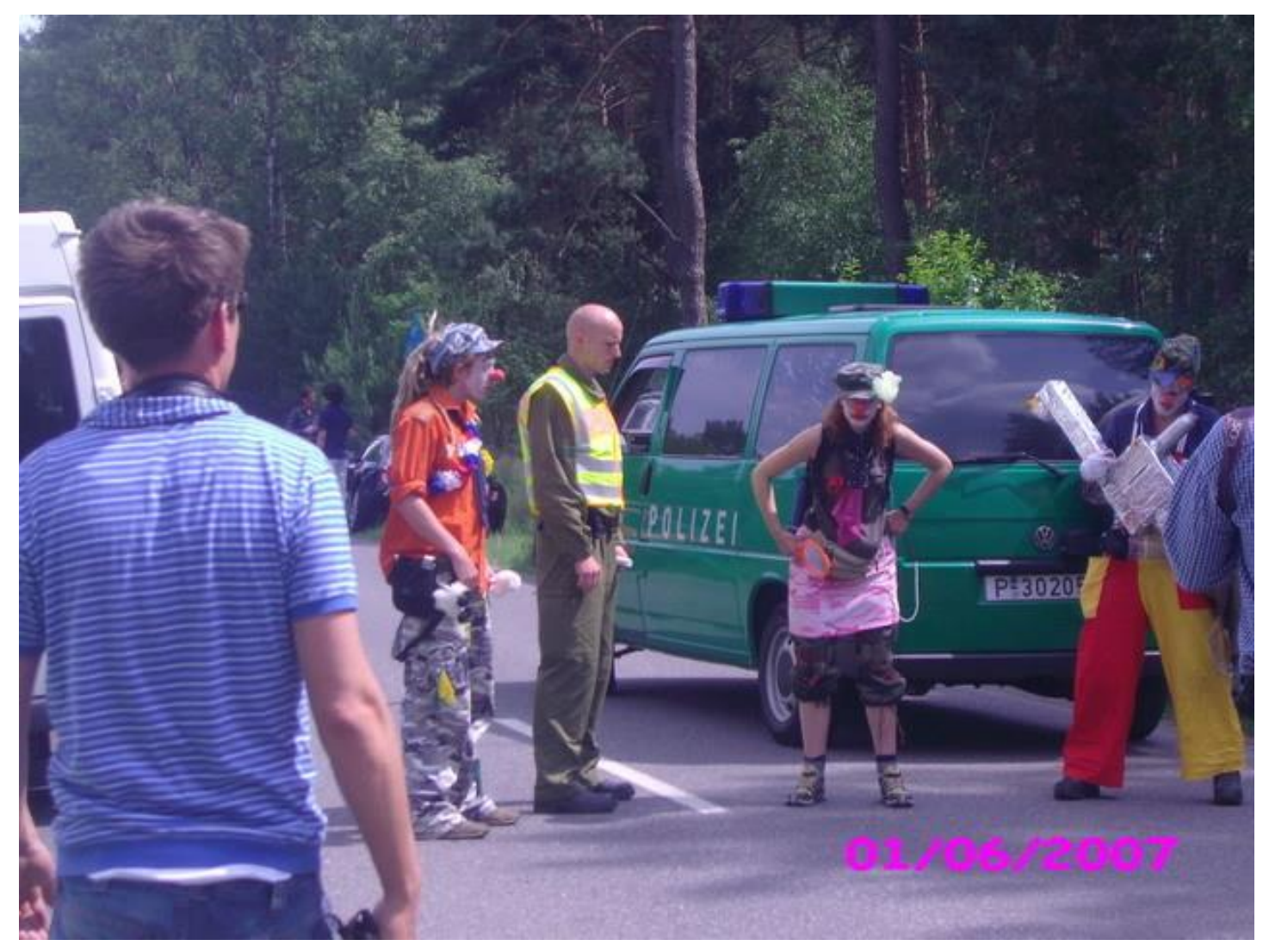

Figure 7. Misunderstandings and bafflement: Which LINE? Are you sure? This LINE? 


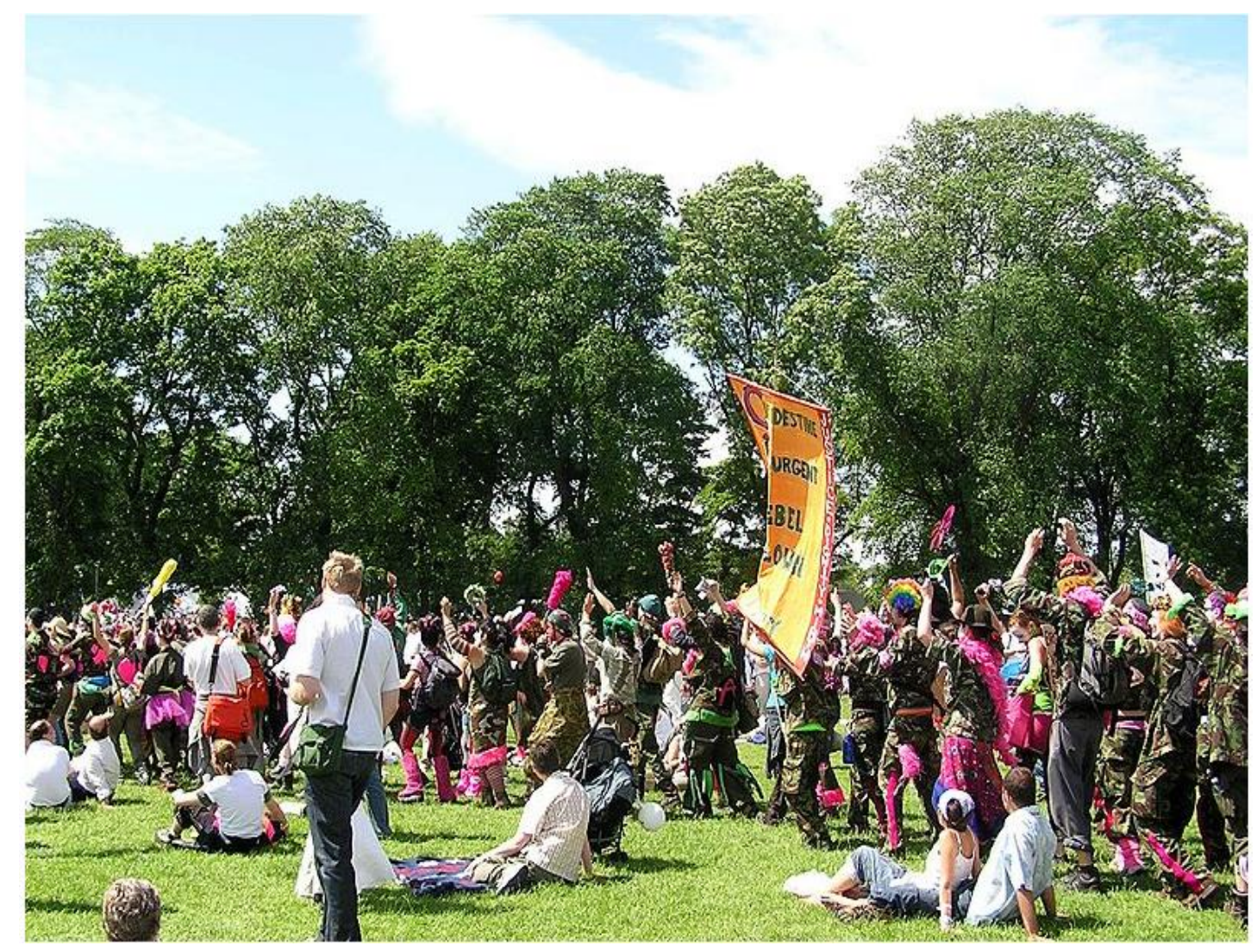

Figure 8. Carnival, celebration, and convivial spaces. 


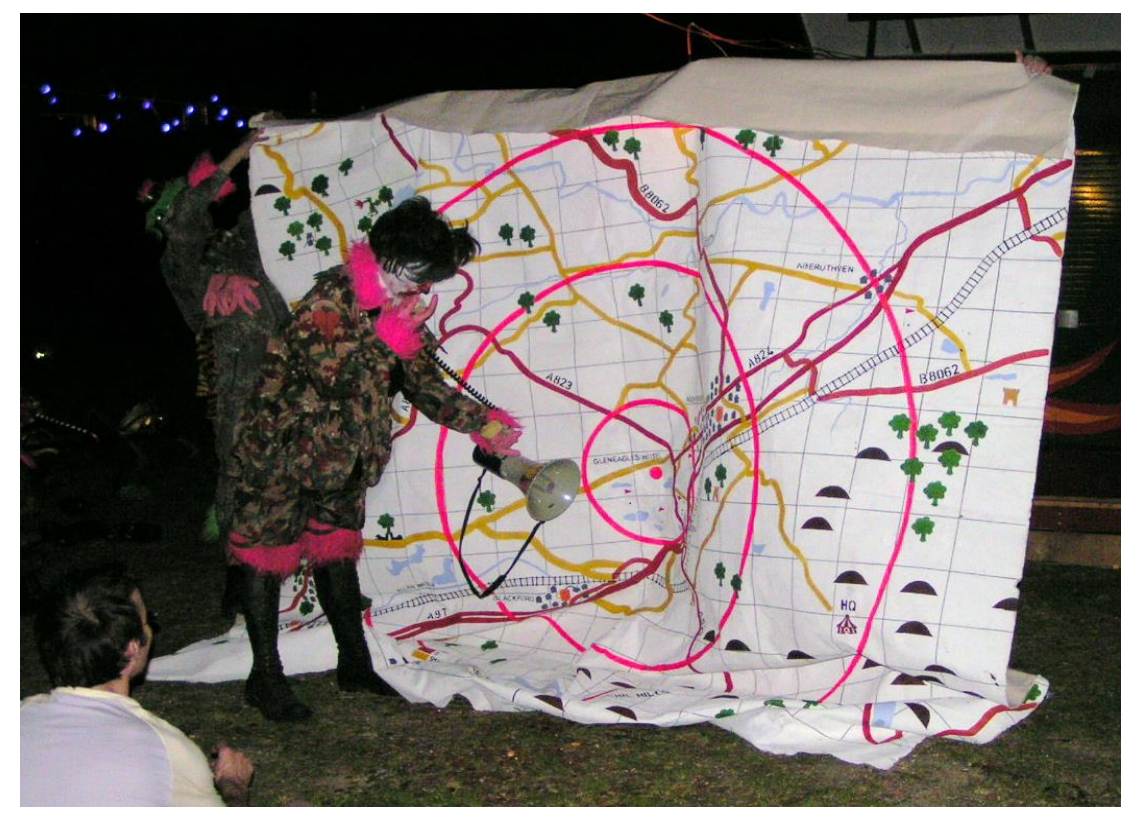

Figure 9. Training Programme for Operation HAHAHA during the Ridiculous Recruitment Show. 


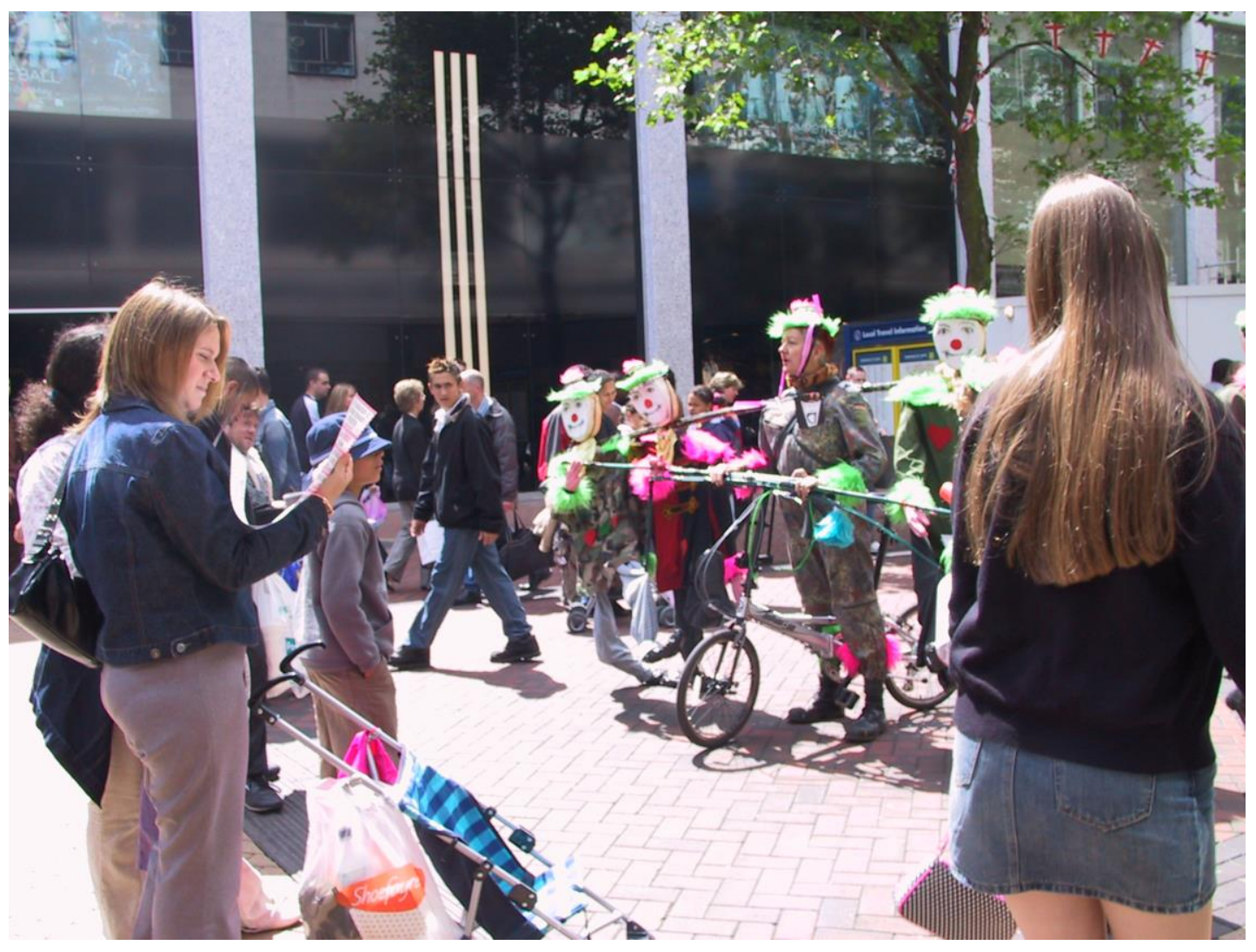

Figure 10. Calling on people to enrol in CIRCA. 


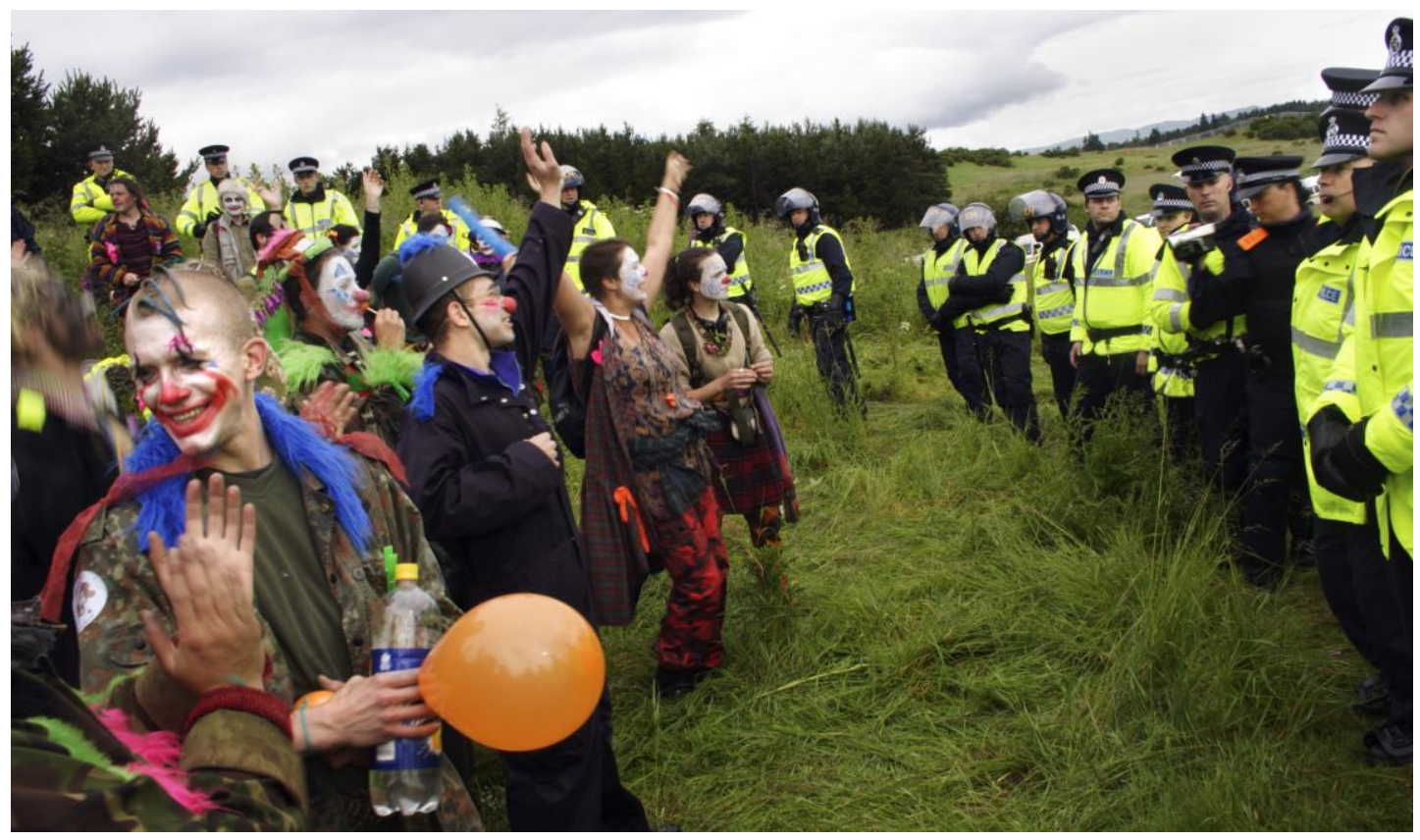

Figure 11. Turning hierarchy on its head: police and rebel clowns play the game of Goblins, Wizards \& Giants.

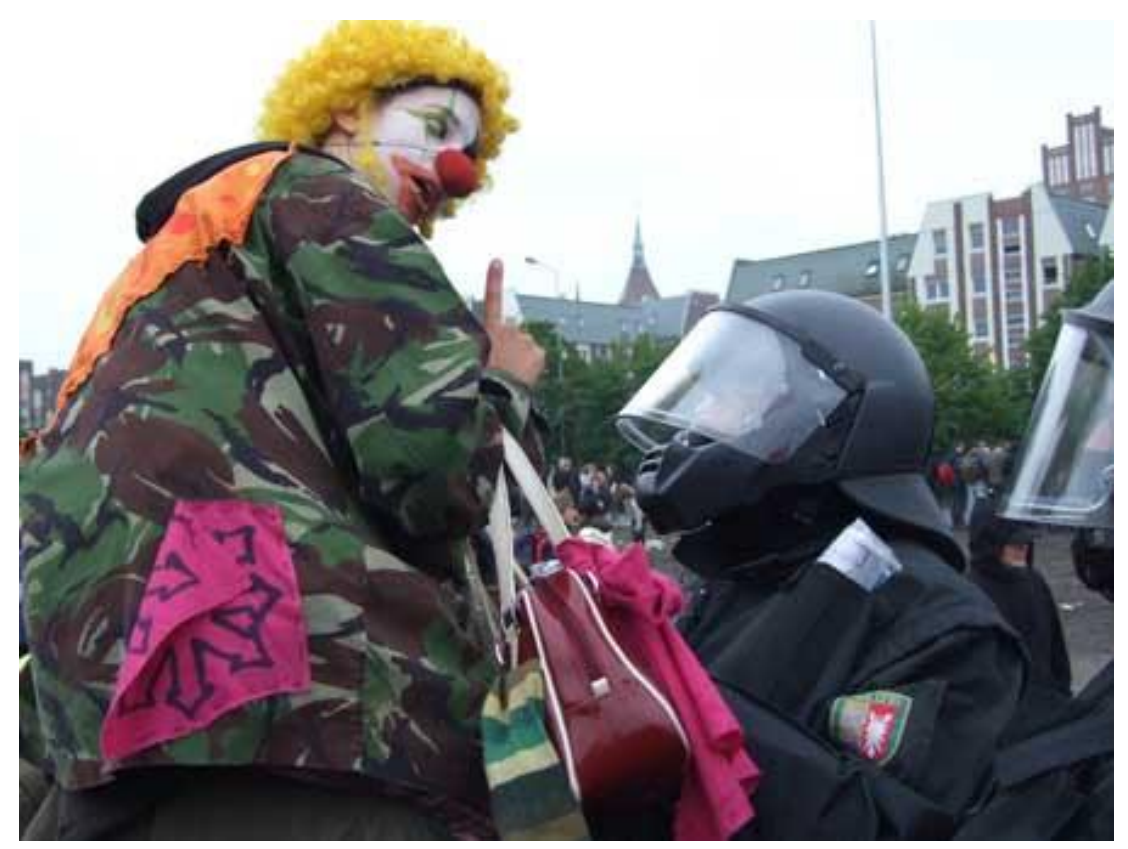

Figure 12. Close-up confrontations: victory over fear and intimidation. 


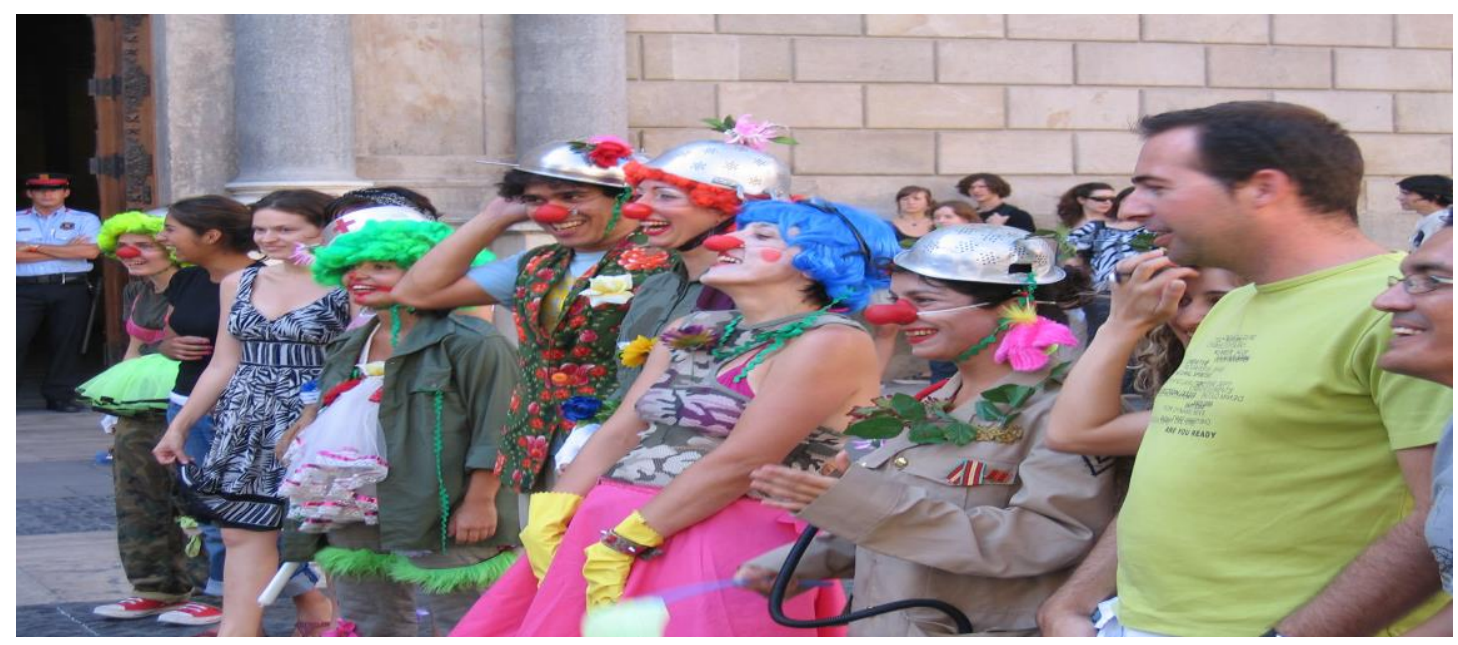

Figure 13. Rebel clowns in Barcelona.

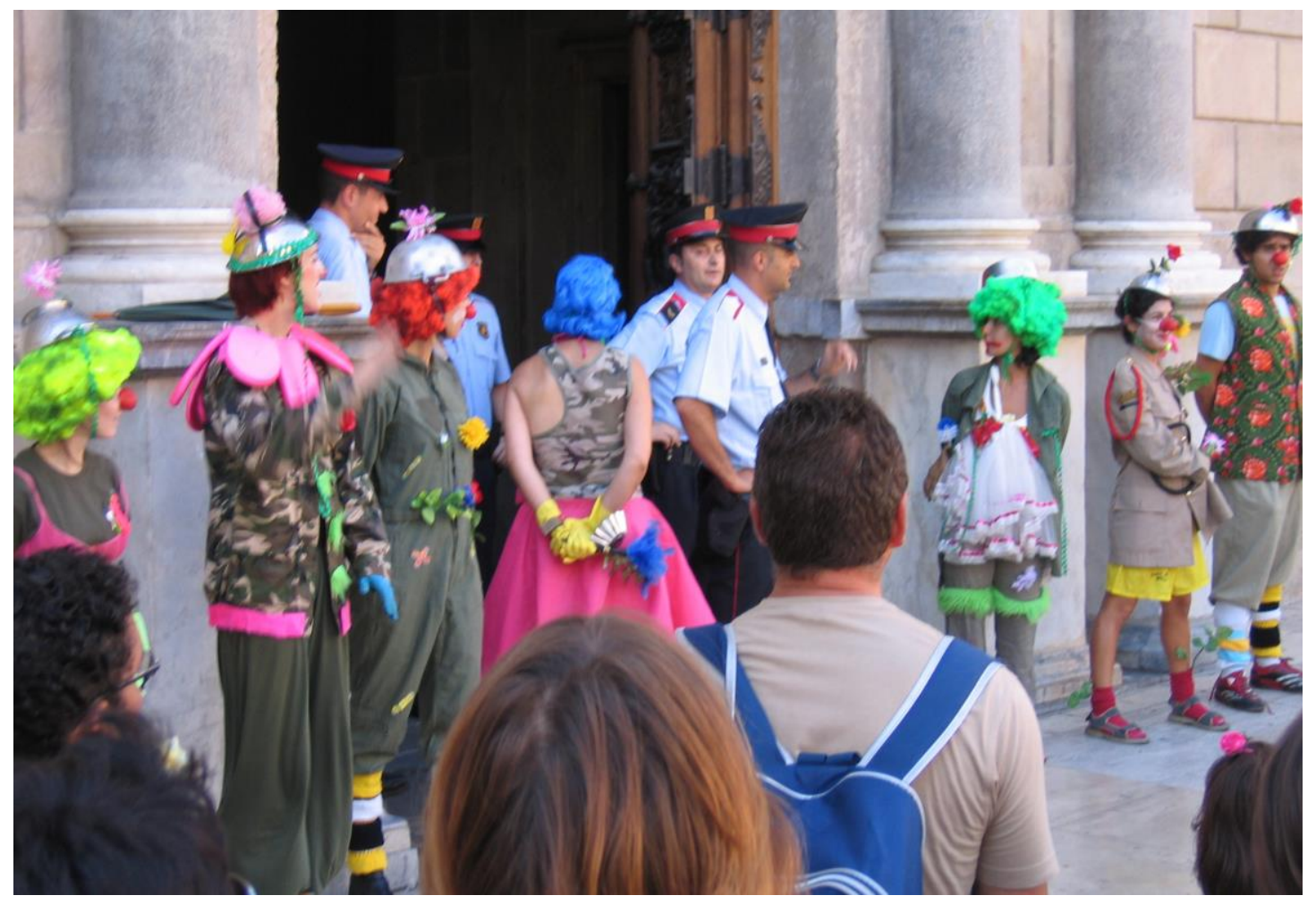

Figure 14. Barcelona clowns assist the security police. 


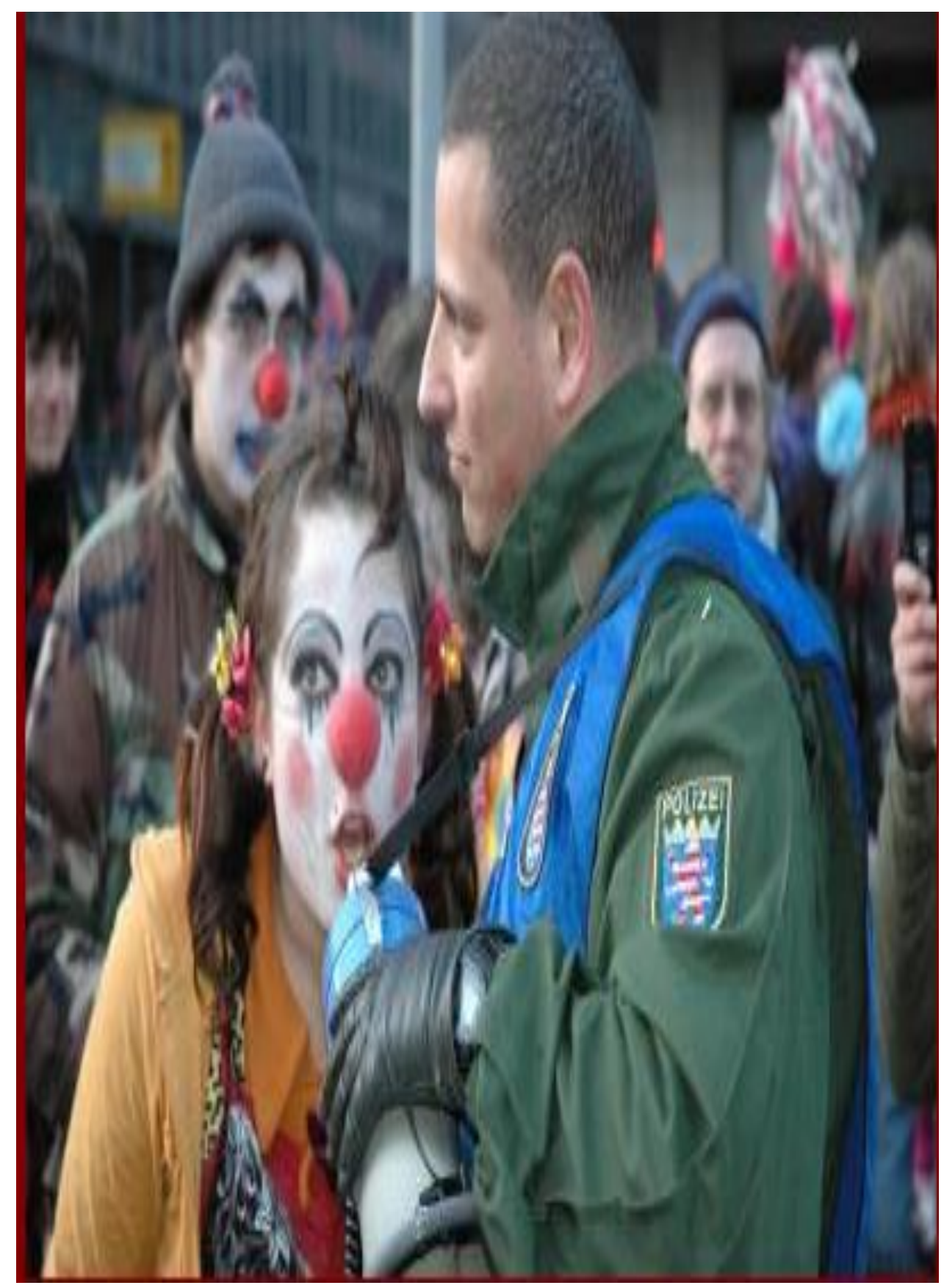

Figure 15. Clowns helping German police with communications.

\section{References}

Bakhtin, M. (1984 [1941]). Rabelais and his World. Indianapolis: University of Indiana Press. Davison, J. (2013). CLOWN, Readings in Theatre Practice. London: Palgrave Macmillan. Feminism and Nonviolence Study Group (1983). Piecing it Together: Feminism and Nonviolence. London: War Resisters' International. 
Fremeaux, I. and Ramsden, H. (2007). 'We disobey to love, rebel clowning for social justice', in Clover, D.E. and Stalker, J. (eds.), The Arts and Social Justice: Recrafting Adult Education and Community Cultural Leadership. Leicester, UK: National of Adult Continuing Education (NIACE), pp. 21-37.

Gaulier, P. (2012). Mes Pensées sur le Théâtre, My Thoughts on Theatre, Bondoufle: Éditions Filmiko.

Grindon, G. (2004). 'Carnival against capital: a comparison of Bakhtin, Vaneigem and Bey', Anarchist Studies 12 (2), pp.147-161.

Klepto, K. (2004). 'Making war with love: The Clandestine Insurgent Rebel Clown Army', City: Analysis of Urban Trends, Culture, Theory, Policy, Action 8 (3), pp. 403-411.

Klepto, K. and Major Up Evil (2005). 'The Clandestine Insurgent Rebel Clown Army goes to Scotland via a few other places', in Harvie, D., Milburn, K., Trott, B. and Watts, D. (eds.), Shut them Down! The G8, Gleneagles 2005 and the Movement of Movements. Leeds: Dissent!, pp. 243-254.

Notes from Nowhere, eds. (2002). We Are Everywhere: The Irresistible Rise of Global Anticapitalism. London/New York: Verso.

Salverson, J. (2009). 'Clown, opera, the atomic bomb and the classroom', in Prentki, T. and Preston, S. (eds.), The Applied Theatre Reader. London \& New York: Routledge, pp. 33-40.

Wright, J. (2006). Why is that so Funny? A Practical Exploration of Physical Comedy. London: Nick Hern Books. 